\title{
INNOVATIVE WORK BEHAVIOUR OF SCHOOL TEACHERS: A CONCEPTUAL FRAMEWORK
}

\author{
Mohammad Fazli Baharuddin ${ }^{1 \star}$, Mohamad Noorman Masrek², \\ Shamila Mohamed Shuhidan ${ }^{3}$ \\ ${ }^{1}$ Faculty of Information Management, UiTM, MALAYSIA, fazli811@uitm.edu.my \\ ${ }^{2}$ Faculty of Information Management, UiTM, MALAYSIA \\ ${ }^{3}$ Faculty of Information Management, UiTM, MALAYSIA \\ ${ }^{*}$ Corresponding Author
}

\begin{abstract}
Education 4.0 will be shaped by innovations and will indeed have to train students to produce innovations. However, in developing a world-class education system which produced a creative and excellent human capital, the weak productivity growth demonstrates the current reality that most of the countries still lack of creativity and innovative as reflected in the stagnant contribution by total factor productivity and education to output growth. Innovative work behaviour can be defined as intentional creation, introduction, and application of new ideas within a work role, in order to benefit the individual or organizational performance. Thus, teachers who have innovative work behaviour are teachers who are able to work creatively, contribute the idea and able to provide positive outcomes for the school where they work. From previous research studies, determinants or antecedents of innovative work behaviour are varying. Those predictors are job commitment, facilities, job autonomy, job insecurity, rewards, and job designs. However, most of the previous literature has believed about job commitment and job autonomy were strong affecting innovative work behaviour. Therefore, this paper aimed to develop a conceptual framework on determinants of innovative work behaviour among school teachers to fill a knowledge gap related to innovative work behaviour in educational institution whose responsible in designed to provide valuable and useful knowledge to students. This paper was explored through critical related literature analysis. The paper concludes that job autonomy and job commitment have a positive impact in creating the essential conditions to encourage teachers to show innovative work behaviour in schools. It is believed that this paper will provide relevant information on innovative work behaviour that would help the government to develop an effective educational reform to benefit its citizens.
\end{abstract}

Keywords: Innovative work behaviour, job autonomy, job commitment, school teacher.

\section{INTRODUCTION}

The emergence of Industrial Revolution 4.0 (IR 4.0) has transformed various things that drive competencies and skills of workforce towards more innovative. Adoption of Industry 4.0 is able to improve productivity, increase efficiency and decrease cost, enhance organization, management and increase the capability of production, enable to improve quality and also enable to develop innovation (Yusof, 2018). Meanwhile, IR 4.0 also has given a new impetus to educational transformation (Xing \& Marwala, 2017). In recent years, education experts recognize the profound impact that a myriad of technological innovations in information and communication technology (ICT) is having on education (Haseeb, 2018). Thus, it can be agreed that 
Education 4.0 will be shaped by innovations and will indeed have to train students to produce innovations (Mirzajani et al., 2016). However, in developing a world-class education system which producing a creative and excellent human capital, the weak productivity growth demonstrates the current reality that most of the countries still lack creativity and innovative as reflected in the stagnant contribution by total factor productivity and education to output growth (National Economic Advisory Council, 2010). It is also stated in New Economic Model published in 2010 which is efforts to innovate and create still insufficient. At the same time, finding from previous research shows the education system is not producing the innovative skills demanded by firms (Serdyukov, 2017). In addition, innovative individuals are indispensable in the field of education, especially school teachers who engage in different teaching and learning process (Thurlings, Evers, \& Vermeulen, 2015). However, most teachers show lacks the desire to innovate in work. Izzati (2018) states that teachers are comfortable in this school, thus they prefer not to develop or introduce new learning strategies and use only conventional learning strategies as usual without noticing that people are heterogeneous and require different methods and approaches.

From an individual point of view, innovative work behavior is defined as the creation, introduction, and application of new ideas in the organization for supporting organizational performance (Ghani, Hussin, \& Jusoff, 2009). It also indicated by Yean, Johari and Yahya (2016) and West and Farr (1990) innovative work behaviour can be defined as intentional creation, introduction and application of new ideas within a work role, in order to benefit the individual or organizational performance. Thus, teachers who have innovative work behaviour are teachers who are able to work creatively, contribute the idea and able to provide positive outcomes for the organization where they work.

Interestingly, Ramamoorthy, Flood, Slattery and Sardessai (2005) pointed out various determinants were lead to innovative work behaviour. From previous research studies, determinants or antecedents of innovative work behaviour are varying. Those predictors are job commitment, facilities, job autonomy, job insecurity, rewards and job designs. However, most of previous literature has believed about job commitment and job autonomy were strong affecting innovative work behaviour (Awang-Hashim, Thaliah, \& Kaur, 2017; Dhar, 2016; Spiegelaere, Gyes, Witte, Niesen, \& Hootegem, 2014; Usma \& Frodden, 2003). However, most of these research studies on innovative work behaviour are focused on service, manufacturing and industrial sectors (Bawuro, 2018). Parthasarathy and Premalatha (2017) argue that research studies on innovative work behaviour have not yet received the level of attention in education field. Meanwhile, Messmann, Mulder and Palonen (2018) mentioned very little study on how teachers have involved in innovation related work behaviours and how their active contributions can be encouraged and fostered. It is against this phenomenon that this paper proposed to fill a knowledge gap related to innovative work behaviour in educational institution whose responsible in designed to provide valuable and useful knowledge to students. Hence, this research aimed to investigate determinants influencing innovative work behaviour of school teachers. It is believed that this study will provide relevant information on innovative work behaviour that would help the government to develop an effective educational reform to benefit its citizens.

\section{INNOVATIVE WORK BEHAVIOUR}

Since the launch of the concept of 'Innovative Work Behaviour (IWB)' in 1994 and 1998 by Scott and Bruce (1994, 1998), the literature using innovative work behaviour has grown steadily. Innovative work behaviour refers to all behaviour of employees that is related to finding, developing, proposing and implementing innovative ideas in the organization in improving innovative performance (Spiegelaere, 2014). Other researcher also defines as the intentional introduction and application within an organization of ideas, processes, products or procedures, new to the unit of adoption, designed to significantly benefit the organization or wider society (Odoardi, 2018). It supported by Climate (2016) described as the intentional creation, introduction and application of new ideas within a work role, group or organization, in order to benefit performance. In the context of education, innovative work behaviour involve changes and improvements in the learning environment for betterment of the students such as the implementation of new methods, tools, technology and contents benefits the learner and enhances the creative potential.

Likewise, innovative work behaviour is generally outlined in the context of how individuals could facilitate the achievement of initiation and intentional introduction of new and useful ideas, processes, products or procedures (Leong \& Rasli, 2014). Innovative work behaviour thus includes behavior of employees that directly and indirectly encourages the development and introduction of innovations on the workplace (Spiegelaere, Gyes, Vandekerckhove, \& Hootegem, 2012). In current working environment, innovative work behaviour is one of the important factors for organizational growth and development in both private and public sectors (Abdullatif, Johari, \& Adnan, 2016). It is aligned with Hakimian et al. (2016) that innovative work behaviour can be as competitive advantage for an organization.

Meanwhile, innovation is often considered as non-continuous activities (Ghani, Hussin, \& Jusoff, 2009). 
Innovation is also seen as a various process with different activities and different innovative work behaviour essential at each stage (Ghani et al., 2009). Therefore, an individual can be anticipated to involve in any blends of these behaviours at any particular time (Dörner, 2012). Innovative work behaviour may result from individual reaction toward high work load (Ramamoorthy et al., 2005). Employees try to adapt themselves to the high work load by generating, promoting and implementing ideas to adapt themselves or work environment (Akram et al., 2015). In ensuring efficiency and to absorb the dynamic change in current competitive market, organizations are increasingly relying on the innovativeness of their employees (Akram et al., 2015). This trend encouraged the organizational scholars to investigate those organizational factors that have a strong impact on the innovative work behaviour of employees (Abdullatif et al., 2016). The review of related literature showed that most previous studies on employees' innovative work behaviour were conducted at the organizational level (Bos-nehles \& Veenendaal, 2017).

There are important arguments to push for innovation in education as a means to maximize the value of public investment. From the previous literatures, there are three main substantial reasons why teachers with innovative work behaviour in schools are required. First, innovative work behaviour is essential in order to keep abreast of rapidly development of society. The demands in our knowledge society are indeed increasing both for students and their teachers (Klaeijsen, Vermeulen, \& Martens, 2017). Second, forthcoming new advancements and new knowledge about teaching is requiring of innovative work behaviour because teachers and their teaching styles in particular have the largest impact on students' selfdetermination towards learning and motivation (Awang-Hashim et al., 2017). Third, schools ought to set a great example and turn as a starting point for more innovative work behaviour of people so that society can stay competitive. It supported by Orindah (2014) innovation is a key driver of economic and social progress. Also, innovation is deliberated as a medium to enhance any organizations' ability to adapt to changing environments (M. Singh \& Sarkar, 2012). After all, education is crucial to promote students' creative and innovative thinking (Usma \& Frodden, 2003). In other words, innovative work behaviour is highly imperative for the persistence development of educational professions as well as school organizations and for knowledge society development.

Relatively few studies focus specifically on school teachers' innovative work behaviour and its determinants (Klaeijsen et al., 2017; Thurlings et al., 2015). Studies among school teachers point at the effects of different factors such as function or task, and self-efficacy (Fairuz et al., 2013), work engagement (P. Runhaar, Bednall, Sanders, \& Yang, 2016), job control and creative requirements (Binnewies \& Gromer, 2012), and openness, motivation, job satisfaction, and interaction within the job (G. Gorozidis \& Papaioannou, 2014; Serdyukov, 2017; Thibaut, Knipprath, Dehaene, \& Depaepe, 2018). Despite these studies show that different motivational factors may contribute to innovative work behaviour. Many studies show, job autonomy (AwangHashim et al., 2017; Jaisingh, 2015; Spiegelaere et al., 2014; Usma \& Frodden, 2003) and job commitment (Dörner, 2012; Lucka, Omara, \& Hassan, 2012; Serdyukov, 2017) have positive impact on innovative works in supporting job performance in any industries including education. On the other hand, the external rewards (salary, position, degree, etc.) that the organization supplies and the internal rewards that are supplied from working environment are the important points as well for encouraging employee in the concept of professional performance (Celep, 2000).

Several previous studies suggested that dimension of innovative work behaviour consists of opportunity exploration, idea generation, idea promotion (championing), and idea realization (implementation) (Akram et al., 2015; Binnewies \& Gromer, 2012; CHombunchoo \& U-On, 2016; Kaur \& Gupta, 2016; Woods, Mustafa, Anderson, Sayer, et al., 2018). In addition, Messmann et al. (2017) enlighten the process of innovation begins at opportunity exploration which involves an awareness of opportunities to strive for something new from an existence of problems (Chatchawan, Trichandhara, \& Rinthaisong, 2017). Opportunity exploration which contributes to the idea generation which defined as a dynamic process of creation and association, generation of representations and categories of opportunities, and communication of ideas which can be in the form of abstract, concrete, or visual (Kheng, Mahmood, et al., 2013). It agreed by Mee (2010) which is the stage for generating new concepts, products, services or process for the purpose of improvement. Idea generation stage is where novel ideas take birth followed by idea promotion. Idea promotion involves the introduction and dissemination of these ideas in the work environment by convincing key actors or key persons and assembling supporters for the innovation process (Messmann et al., 2017). It can also be referred to someone without a formal role who is able to move forward a new service by overcoming all the possible organizational barriers (Leong \& Rasli, 2014). Idea promotion which is aimed at gaining the group's approval, and necessary resources for idea realization or also known as the stage of implementation. At the point when the organization have decided to develop, test and commercialize, idea realization or the implementation is taking place (Jong \& Hartog, 2010) and innovation is thus becoming part of the organization working process (Kheng, Mahmood, et al., 2013). 


\section{JOB AUTONOMY}

One of such perceived contextual factors is job autonomy. This concept is regarded as the main shaper of worker's attitudes, motivation and behavior (Sazandrishvili, 2009). Job autonomy concerns the extent to which employees have a power in organizing their job activities (Ramamoorthy et al., 2005). According to Spiegelaere et al. (2014), autonomy refers to the degree of control of an employee over how to carry out the job task. Autonomy enables employees to experiment with different work approaches and methods. It also enables them to find ideas and develop them further through the small-scale application of these ideas (Slåtten \& Mehmetoglu, 2011). Based on Spiegelaere (2014), job autonomy refers to the decision latitude of employees to decide about how to approach the work. Job autonomy (or sometimes also referred to as job control) is seen as a powerful job resource which is motivating in itself and enables employees to cope with high job demands (Spiegelaere, 2014).

The literature identified job autonomy as an important antecedent of an employee's creativity and innovative work behaviour as well (Akram et al., 2015; Ramamoorthy et al., 2005; Spiegelaere et al., 2012; Usma \& Frodden, 2003; Werleman, 2016). Therefore, if job autonomy showing a significant effect, innovation managers should give employees enough discretion in how they perform their work tasks (Werleman, 2016). Among the earliest discussions on innovative work behaviour was Hackman and Oldham (1980). They described autonomy as the degree of control of an employee over how to carry out the job task. Job autonomy enables employees to experiment with different work approaches and methods. It enables them to find ideas and develop them further through the small-scale application of these ideas. Moreover, previous research also found that in jobs with fully autonomous, employees tend to participate more in knowledge sharing (P. Runhaar et al., 2016). As a result, research identified job autonomy as a strong relationship with employee innovative work behaviour (Messmann et al., 2017; Rahman, Panatik, \& Alias, 2014; Ramamoorthy et al., 2005; Sharifirad, 2013; Spiegelaere, 2014; Thurlings et al., 2015).

Furthermore, job autonomy has been validated to have the strongest impact on innovative work behaviour. For instance, job autonomy enables employees to generate different work approaches and methods, and supports employees in implementing ideas (Werleman, 2016). Moreover, job autonomy also permits employees to find more efficient and effective ways of doing their work (Mee, 2010; Ramamoorthy et al., 2005; Spiegelaere et al., 2014). As a result, there is a reason to believe that the motivational variables that promote proactive behaviour might be similar in promoting innovative work behaviour, these both concepts are related (Messmann et al., 2017). In addition, for innovative work behaviour, job autonomy plays significant functions. First, it provides the employees with a sense of control over their work and is likely to increase the overall intrinsic motivation of employees which is a major trigger for employee creativity. Second, it gives employees the necessary space to experiment with alternative work procedures and methods that they can propose as an innovation in a later stadium. Third, high job autonomy increases the employee's feelings of responsibility towards his job, which should in turn increase proactive behaviour such as idea generation and suggestion (Ohly \& Fritz, 2009; Spiegelaere, 2014).

Hence, job autonomy or freedom may permit employees to engage in 'trial and error' and find more efficient and effective ways of doing their work (Kheng, Mahmood, et al., 2013). Since innovation involves trial and error, and successes and failures, job autonomy provides employees with an avenue to try out new ideas even in the face of failure. Autonomy eliminates the need for the employees to work within a prescribed set of bureaucratic rules and regulations. Furthermore, autonomy has also been shown to be one of the critical components that employees have come to expect from their employment (Ramamoorthy et al., 2005).

Nevertheless, autonomy has also been widely contested in philosophy, and the concept has been defined in a variety of ways especially in educational. In educational research as well, the concept has been debated from varying viewpoints, as, for example, scholars engaged in education history (Wermke \& Salokangas, 2015), education sociology and policy, legal issues (Spiegelaere et al., 2014; Wermke \& Salokangas, 2015) and pedagogy (Ghani et al., 2016) have all problematized and defined its meaning in relation to education. Meanwhile, Jaisingh (2015) and Serdyukov (2017) were focusing on innovative work behaviour towards school teachers and phenomenon. Therefore, Awang-Hashim et al. (2017) mentions highly controlling teachers tend to modify behaviours through the use of external controls such as rewards, setting limits, using directive and do not nurture inner motivational resources. On the other hand, teachers who seek to minimize external controls and attempt to take the student's internal frame of reference with respect to problems, ideas and initiatives are considered to be autonomy supportive (Messmann et al., 2017).

\section{JOB COMMITMENT}

Often in many cases, ideas on innovation do not come from knowledge workers that have been specifically appointed by the entrepreneur but rather ideas came from people who were truly committed and believe that 
their ideas will be accepted by others as well (Kheng, Mahmood, et al., 2013). Commitment has gained substantial interest in organizational research. It is believed that committed employees demonstrate differing degrees of organizational and individual outcomes such as employee turnover, performance, and their intention to stay or leave an organization. Furthermore, the competitive business environment leads organizations to rely on human capital. With regard to employees, organizations need to consider fundamental factors, such as commitment. Committed employees are a vital and fundamental resource for the success and performance of business organizations (Hakimian et al., 2016). A similar scenario also occurs in the educational setting, especially in schools. Having a highly committed teacher is regarded as an asset in any school (Thien et al., 2014). Based on previous research by Orindah (2014) found that $57 \%$ of the teachers agreed that they are not committed due to poor remuneration and normally, feelings of dissatisfaction occur because they are not involved in decision-making process especially in teaching and there is no teamwork or collaboratively works. In addition, $88 \%$ of the teachers were highly committed when given permission for creativity (Orindah, 2014).

Review of the literature revealed large numbers of studies on organizational commitment (Fairuz et al., 2013; Holliman, 2012; Li \& Zheng, 2014). The model of commitment was then developed in 1987 by Meyer and Allen, in three forms; affective commitment, continuance commitment and normative commitment (Hakimian et al., 2016). The study they conducted provided evidence that these attitudinal commitment components (affective, continuance and normative) were conceptually and empirically separable, but were not necessarily inter-correlated. There are many benefits to organizations with committed employees, including cost reduction, better performance, less absenteeism and higher productivity (Ramamoorthy et al., 2005). According to Celep (2000), close relationships of the teacher's commitment to their schools, the work group, and the teaching occupation were found out and a direct relationship was discovered between the teachers' organizational commitment and having a proper pride to belong to such a school and work group. It agreed by Thien et al. (2014), the dimensions of teachers' commitment are commitment to students, commitment to teaching, commitment to school and commitment to profession. Meanwhile, it is expected that commitment positively impacts innovative work behaviour (Werleman, 2016). It supported by Thien et al. (2014) where teachers' commitment support their ability to innovate and to integrate new ideas into their own practice.

\section{PROPOSE FRAMEWORK AND CONCLUSION}

School teacher in the digital era is a complex endeavour, as teachers' role is constantly changing, from being the major source of knowledge to being a person who responsible to prepare students to feel confident in innovation-oriented settings. Hence, the school teacher requires knowledge, skills, competencies and dispositions required to transform education in order to meet society's changing needs. With the inclusion of new competencies, the innovative work behaviour of teachers confidently will improve to produce a profitable outcome. Therefore, besides resolving knowledge gaps, this paper aims to be part of the solution by providing further understanding on determinants of current innovative work behaviour of school teachers so that future improvement can be strategically planned for a better nation. As a result, this paper proposes a framework on determinants of innovative work behaviour that can be used to support school teachers.

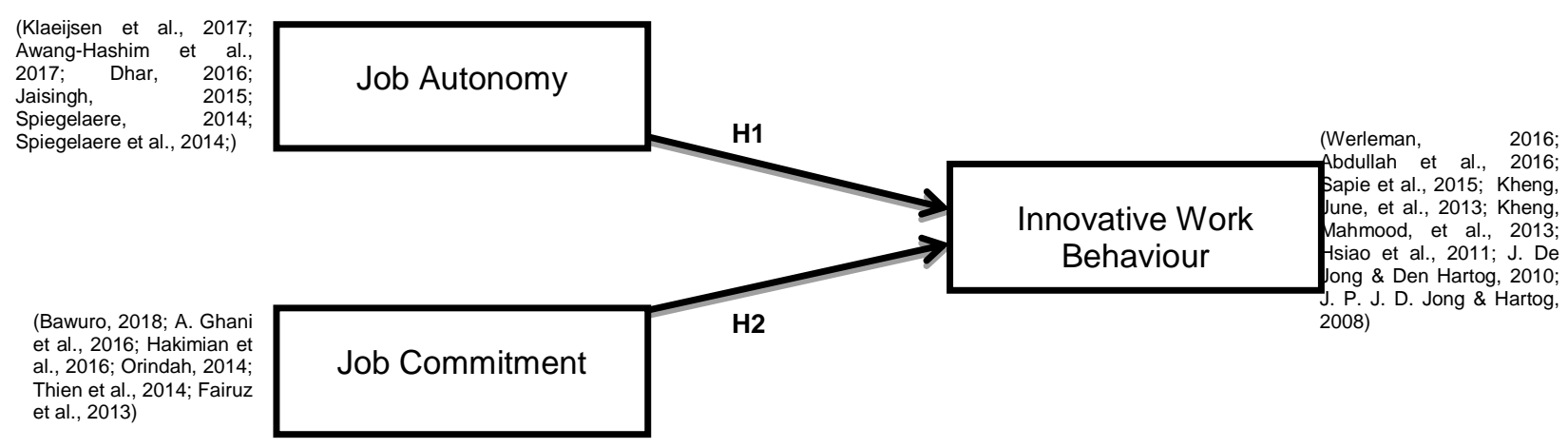

Figure 1: Proposed framework showing the relationship between job autonomy, job commitment and innovative work behaviour of school teachers

Figure 1 shows the relationship between job autonomy, job commitment and innovative work behaviour of school teachers. The framework shows that job autonomy and job commitment shows directly influence and affecting innovative work behaviour. This proposition aligned with initial innovative work behaviour concepts by previous studies. According to Spiegelaere (2014), job autonomy has frequently been identified as one of 
the major antecedents of employee creativity and increases the making of suggestions for improvements in any innovation development. Ramamoorthy et al. (2005) that study on 204 employees from Irish manufacturing organizations mentioned that job autonomy or freedom may permit employees to engage in 'trial and error' and find more efficient and effective ways of doing their work. Meanwhile Ohly and Fritz (2009) state high job autonomy increases the employee's feelings of responsibility towards his job, which should in turn increase proactive behaviour such as idea generation and suggestion. Therefore, Binnewies and Gromer (2012) concluded that idea generation was positively influenced by job autonomy and creative requirements whereby teachers should feel they have control over their jobs, and at the same time, they need to be challenged to be creative. In fact, job commitment one of crucial determinant for innovative work behaviour. Bawuro (2018) has mentions job commitment to the organization will influence their ability to innovative, share knowledge tackle work-based issues. In support, Thien et al. (2014) agree that teachers' commitment supports students' ability to innovate and to integrate new ideas into their own practice. As a result, this paper proposes a framework on determinants of innovative work behaviour that can be used to support school teachers. The framework demonstrates relationship between job autonomy, job commitment and innovative work behaviour. The proposed conceptual framework can be used to help education institutions especially school in recognizing current teacher's innovation work behaviour by utilizing the instrument from this study as the relationship between these factors can be examined. By identifying an area of improvement needed to improve innovation in education, this study expectantly will aid government's efforts in developing world-class education system and focus on the aspect of dynamic and innovative human capital in enhancing its resilience and economic progress, as well as developing a community with exemplary values.

\section{REFERENCE LIST}

Abdullatif, T. N., Johari, H. bt, \& Adnan, Z. bt. (2016). The Impact of Psychological Empowerment on Innovative Work Behavior Moderating by Quality Culture. European Journal of Business and Management, 8(17), 126-131.

Akram, T., Haider, M. J., \& Feng, Y. X. (2015). The Effects of Organizational Justice on the Innovative Work Behavior of Employees: An Empirical Study from China. Journal of Creativity and Business Innovation, 2, 114-126.

Awang-Hashim, R., Thaliah, R., \& Kaur, A. (2017). A cultural insight into the development of teacher autonomy support scale A self-determination theory perspective. Journal for Multicultural Education, 11(4). https://doi.org/10.1108/JME-09-2016-0050

Bawuro, F. A. (2018). Factors Influencing Innovative Behaviour of Teachers in Secondary Schools in the North East of Nigeria. Path of Science, 4(3), 1007-1017. https://doi.org/10.22178/pos.32-9

Binnewies, C., \& Gromer, M. (2012). Creativity and innovation at work: The role of work characteristics and personal initiative. Psicothema, 24(1), 100-105.

Bos-nehles, A. C., \& Veenendaal, A. A. R. (2017). Perceptions of HR practices and innovative work behavior: the moderating effect of an innovative climate. The International Journal of Human Resource Management, 5192, 1-23. https://doi.org/10.1080/09585192.2017.1380680

Celep, C. (2000). Teachers' Organizational Commitment in Educational Organizations. National FORUM of Teacher Education Journal, 10E(3), 22.

Chatchawan, R., Trichandhara, K., \& Rinthaisong, I. (2017). Factors Affecting Innovative Work Behavior of Employees in Local Administrative Organizations in the South of Thailand. International Journal of Social Sciences and Management, 4(3), 154-157. https://doi.org/10.3126/ijssm.v4i3.17755

CHombunchoo, N., \& U-On, V. (2016). The Competency and Innovative Work Behavior Of Rajchapat University in Thailand. Middle-East Journal of Scientific Research, 24(5), 1594-1599. https://doi.org/10.5829/idosi.mejsr.2016.24.05.23475

Climate, C. (2016). The Mediating Role of Psychological Empowerment on the Relationship between Creative Climate and Innovative Work Behavior: The Case of Employees of Various Sectors in Turkey. Journal of Behavior at Work, 1(1), 74-84. 
Dhar, R. L. (2016). Ethical leadership and its impact on service innovative behavior: The role of LMX and job autonomy. Tourism Management, 57, 139-148. https://doi.org/10.1016/j.tourman.2016.05.011

Dörner, N. (2012). Innovative Work Behavior: The Roles of Employee Expectations and Effects on Job Performance.

Fairuz, S., Nordin, N., Anida, A., \& Sirun, N. (2013). A study on primary school teachers' organizational commitment and psychological empowerment in the district of klang. Procedia - Social and Behavioral Sciences, 90, 782-787. https://doi.org/10.1016/j.sbspro.2013.07.152

Ghani, N. A. A., Hussin, T. A. B. S. R., \& Jusoff, K. (2009). The Impact of Psychological Empowerment on Lecturers ' Innovative Behaviour in Malaysian Private Higher Education Institutions. Canadian Social Science, 5(4), 54-62.

Gorozidis, G., \& Papaioannou, A. G. (2014). Teachers' motivation to participate in training and to implement innovations. Teaching and Teacher Education, 39, 1-11. https://doi.org/10.1016/j.tate.2013.12.001

Hakimian, F., Farid, H., Ismail, M. N., \& Nair, P. K. (2016). Importance of commitment in encouraging employees' innovative behaviour. Asia-Pacific Journal of Business Administration, 8(1), 70-83. https://doi.org/10.1108/APJBA-06-2015-0054

Haseeb, A. S. M. A. (2018). Higher education in the era of IR 4. New Straits Times. Retrieved from https://www.nst.com.my/education/2018/01/323591/higher-education-era-ir-40

Izzati, U. A. (2018). The Relationships between Vocational High School Teachers ' Organizational Climate and Innovative Behavior. Advances in Social Science, Education and Humanities Research, 173(ICEI 2017), 343-345.

Jaisingh, K. (2015). Teacher Autonomy: How Far and to What Extent in ESL Classroom? International Journal of Innovative Research \& Development, 4(3), 25-27.

Jong, J. P. J. D., \& Hartog, D. N. Den. (2008). Innovative Work Behavior: Measurement and Validation. Scientific Analysis of Entrepreneurship and SMEs, (November), 1-27. https://doi.org/10.4236/ajibm.2015.54022

Kaur, K. D., \& Gupta, V. (2016). The Impact of Personal Characteristics on Innovative Work Behaviour: An Exploration into Innovation and Its Determinants amongst Teachers. The International Journal of Indian Psychology, 3(3).

Kheng, Y. K., June, S., \& Mahmood, R. (2013). The Determinants of Innovative Work Behavior in the Knowledge Intensive Business Services Sector in Malaysia. Asian Social Science, 9(15), 47-59. https://doi.org/10.5539/ass.v9n15p47

Kheng, Y. K., Mahmood, R., \& Beris, S. J. H. (2013). A Conceptual Review of Innovative Work Behavior in Knowledge Intensive Business Services among Knowledge Workers in Malaysia. International Journal of Business, Humanities and Technology, 3(2), 91-99.

Klaeijsen, A., Vermeulen, M., \& Martens, R. (2017). Teachers' innovative behaviour: the importance of basic psychological need satisfaction, intrinsic motivation, and occupational self-efficacy. Scandinavian Journal of Educational Research, 19-39.

Leong, C. T., \& Rasli, A. (2014). The Relationship between innovative work behavior on work role performance: An empirical study. Procedia - Social and Behavioral Sciences, 129, 592-600. https://doi.org/10.1016/i.sbspro.2014.03.717

Lucka, L. T., Omara, N. B., \& Hassan, W. H. A. B. W. (2012). Regional Teachers and Academics LMS - An Innovative and Collaborative Platform to Support Life Long Learning and Training for Teachers and Academics. Procedia - Social and Behavioral Sciences, 67, 250-259. https://doi.org/10.1016/i.sbspro.2012.11.327

Mee, L. S. (2010). Determinants of Innovative Work Behavior among White-Collar Workers: A study of the Manufacturing Firms within the Electrical and Electronic (ETE) Sector of Penang.

Messmann, G., Mulder, R. H., \& Palonen, T. (2018). Vocational education teachers' personal network at school as a resource for innovative work behaviour. Journal of Workplace Learning, 30(3), 174-185. https://doi.org/10.1108/JWL-08-2017-0069

Messmann, G., Stoffers, J., Heijden, B. Van Der, \& Mulder, R. H. (2017). Joint effects of job demands and job resources on vocational teachers' innovative work behavior. Personnel Review, 46(8), 1948-1961. 
https://doi.org/10.1108/PR-03-2016-0053

Mirzajani, H., Bayekolaei, M. D., Kookandeh, M. R., Rezaee, S. S. R., Kamalifar, A. A., \& Shani, H. R. (2016). Smart Schools an Innovation in Education: Malaysian's Experience. Asian Journal of Education and Training, 2(1), 11-15. https://doi.org/10.20448/journal.522/2016.2.1/522.1.11.15

National Economic Advisory Council. (2010). New Economic Model for Malaysia.

Odoardi, G. (2018). The relationship of perceived human resources management practices and innovative work behavior.

Ohly, S., \& Fritz, C. (2009). Work characteristics, challenge appraisal, creativity, and proactive behavior: A multi-level study. Journal of Organizational Behavior, 31(4), 543-565.

Orindah, F. A. (2014). Influence of organizational culture on teachers' job Commitment in public primary schools in ndhiwa subcounty, Kenya.

Parthasarathy, J., \& Premalatha, T. (2017). Impact of Collective-Efficacy and Self-Efficacy on the Innovative Work Behaviour of Teachers in the Nilgiris District, Tamil Nadu. The International Journal of Indian Psychology, 5(1). https://doi.org/10.25215/0501.019

Rahman, A. A. A., Panatik, S. A., \& Alias, R. A. (2014). The Influence of Psychological Empowerment on Innovative Work Behavior among Academia in Malaysian Research Universities. IPEDR, 78(21), 108112. https://doi.org/10.7763/IPEDR.

Ramamoorthy, N., Flood, P. C., Slattery, T., \& Sardessai, R. (2005). Determinants of Innovative Work Behaviour: Development and Test of an Integrated Model. Creativity and Innovation Management, 14(2), 142-150.

Runhaar, P., Bednall, T., Sanders, K., \& Yang, H. (2016). Promoting VET teachers' innovative behaviour: exploring the roles of task interdependence, learning goal orientation and occupational self- efficacy Piety. Journal of Vocational Education \& Training, (August 2017), 1-17. https://doi.org/10.1080/13636820.2016.1231215

Sazandrishvili, N. (2009). Contextual and Personal Antecedents of Innovative Behavior.

Scott, S. G., \& Bruce, R. A. (1994). Determinants of Innovative Behavior: A Path Model of Individual Innovation in the Workplace. The Academy of Management Journal, 37(3), 580-607.

Serdyukov, P. (2017). Innovation in education: what works, what doesn't, and what to do about it? Journal of Research in Innovative Teaching \& Learning, 10(1), 4-33. https://doi.org/10.1108/JRIT-10-2016-0007

Sharifirad, M. S. (2013). Transformational leadership, innovative work behavior, and employee well-being. Glob Bus Perspect, 1, 198-225. https://doi.org/10.1007/s40196-013-0019-2

Singh, M., \& Sarkar, A. (2012). The Relationship Between Psychological Empowerment and Innovative Behavior: A Dimensional Analysis With Job Involvement. Journal of Personnel Psychology, 11(3), 127-137. https://doi.org/10.1027/1866-5888/a000065

Slåtten, T., \& Mehmetoglu, M. (2011). What are the drivers for innovative behavior in frontline jobs? A study of the hospitality industry in Norway. Journal of Human Resources in Hospitality and Tourism, 10(3), 254-272. https://doi.org/10.1080/15332845.2011.555732

Spiegelaere, S. De. (2014). The Employment Relationship and Innovative Work Behaviour.

Spiegelaere, S. De, Gyes, G. Van, Vandekerckhove, S., \& Hootegem, G. Van. (2012). Job Design and Innovative Work Behavior.

Spiegelaere, S. De, Gyes, G. Van, Witte, H. De, Niesen, W., \& Hootegem, G. Van. (2014). On the Relation of Job Insecurity, Job Autonomy, Innovative Work Behaviour and the Mediating Effect of Work Engagement. Creativity and Innovation Management, 23(3), 318-330.

Thibaut, L., Knipprath, H., Dehaene, W., \& Depaepe, F. (2018). The influence of teachers' attitudes and school context on instructional practices in integrated STEM education. Teaching and Teacher Education, 71, 190-205. https://doi.org/10.1016/j.tate.2017.12.014

Thurlings, M., Evers, A. T., \& Vermeulen, M. (2015). Toward a Model of Explaining Teachers' Innovative Behavior: A Literature Review. Review of Educational Research, 85(3).

https://doi.org/10.3102/0034654314557949 
Usma, J., \& Frodden, C. (2003). Promoting Teacher Autonomy through Educational Innovation*. Íkala, Revista de Lenguaje Y Cultura, 8(4), 101-132.

Werleman, A. A. (2016). Master Thesis Human Resources Studies The Effect of Enriched Job Design on Innovative Work Behaviour.

Wermke, W., \& Salokangas, M. (2015). Autonomy in education: theoretical and empirical approaches to a contested concept. Nordic Journal of Studies in Educational Policy, 317. https://doi.org/10.3402/nstep.v1.28841

West, M. A., \& Farr, J. L. (1990). Innovation and Creativity at Work. Oxford: John Wiley.

Woods, S. A., Mustafa, M. J., Anderson, N., \& Sayer, B. (2018). Innovative work behavior and personality traits Examining the moderating effects of organizational tenure. Journal of Managerial Psychology, 33(1), 29-42. https://doi.org/10.1108/JMP-01-2017-0016

Xing, B., \& Marwala, T. (2017). Implications of the Fourth Industrial Age on Higher Education. Computers and Society.

Yean, T. F., Johari, J., \& Yahya, K. K. (2016). Contextualizing Work Engagement and Innovative Work Behaviour: The Mediating Role of Learning Goal Orientation. In The European Proceedings of Social \& Behavioural Sciences.

Yusof, Y. (2018). A Novel Framework and Strategies Supporting IR 4.0 relation to Manufacturing Process. 